\title{
Protective Effects of Royal Jelly against Cyclophosphamide-Induced Liver Damage
}

\section{Siklofosfamid Kaynaklı Karaciğer Hasarına Karşı Arı Sütünün Koruyucu Etkisi}

\author{
Ebru Annaç¹, Ali Tekçe², Ömer Korkmaz², Mehmet Bülbül ${ }^{3}$, Mustafa Demirci ${ }^{4}$ \\ ${ }^{1}$ Adıyaman Üniversitesi Tıp Fakültesi, Histoloji Ve Embriyoloji Ana Bilim Dalı, Adıyaman \\ ${ }^{2}$ Harran Üniversitesi Veteriner Hekimliği Fakültesi, Doğum Ve Jinekoloji Ana Bilim Dalı, Şanlıurfa \\ ${ }^{3}$ Adıyaman Üniversitesi Tıp Fakültesi, Kadın Hastalıkları Ve Doğum Ana Bilim Dalı, Adıyaman \\ ${ }^{4}$ Gerger Tarım Ve Orman İlçe Müdürlüğü, Adıyaman
}

Dergiye Ulaşma Tarihi: 06.01.2020 Dergiye Kabul Tarihi: 30.06.2020 Doi: 10.5505/aot.2020.26817

\section{ÖZET}

GİRIŞ ve AMAÇ: Bu çalışmada, arı sütünün Siklofosfamid (CP) ile indüklenmiş Karaciğer hasarının yol açtığı histopatolojik değișiklikler üzerinde koruyucu etkileri değerlendirildi.

YÖNTEM ve GEREÇLER: Çalışmada 32 Wistar albino cinsi sıçan rastgele 4 gruba ayrıldı: Kontrol (0.5 cc serum fizyolojik 16 gün boyunca oral yolla verildi), Arı Sütü Grubu (100 mg / kg arı sütü 16 gün boyunca oral yolla verildi), $\mathrm{CP}$ grubu (100 mg / kg intraperitoneal (tek doz) CP enjekte edildi), CP+Arı sütü grubu (100 mg / kg intraperitoneal CP enjekte edildi ve ayrıca 16 gün boyunca $100 \mathrm{mg} / \mathrm{kg}$ arı sütü oral yolla verildi). Deneysel çalışma tamamlandıktan sonra, her bir hayvandan karaciğer dokuları çıkarıldı ve \% 10 formaldehit içerisinde fikse edildi. Ardından karaciğer dokuları histopatolojik olarak incelendi.

BULGULAR: Kontrol ve Arı sütü ile muamele edilen gruplardaki karaciğer dokusunun morfolojik olarak normal bir histolojik yapıya sahip olduğu gözlendi. Ancak, CP uygulanan grupta hepatositlerde dejenerasyon, sinüzoidal dilatasyon ve inflamasyon gibi toksik etkiler saptandı. CP ile birlikte Arı sütü uygulanan grupta arı sütünün antioksidan özelliği sayesinde karaciğer dokusunda CP kaynaklı yapısal değişiklikleri onardığı ve toksik etkiye karşı koruduğu tespit edildi.

TARTIŞMA ve SONUÇ: Arı sütü, CP'nin neden olduğu hepatotoksisiteye karşı koruyucu bir doğal ürün olabilir. Anahtar Kelimeler: Siklofosfamid, Arı sütü, Karaciğer, Histopatoloji

\begin{abstract}
INTRODUCTION: The aim of the present study to evaluate the protective effects of Royal Jelly on the changes caused by Cyclophosphamide (CP)- induced liver damage.

METHODS: 32 Wistar albino rats were divided randomly into 4 groups: Control (0.5 cc saline was given orally for 16 days), Royal Jelly group (100 mg / kg Royal Jelly was given orally for 16 days) CP group (100 mg / kg intraperitoneal (singledose) CP was injected), CP+Royal Jelly group (100 mg / kg intraperitoneal CP was injected and also $100 \mathrm{mg} / \mathrm{kg}$ Royal Jelly was given orally for 16 days). After the experimental study was completed, liver tissues were removed from each animal and fixed in $10 \%$ formaldehyde. And then liver tissues were examined histopathologically.

RESULTS: The liver tissue of the Control with the Royal Jelly treated groups had normal histological structures. However, toxic effects were observed such as degeneration of hepatocytes, sinusoidal dilatation and inflammation in the cyclophosphamide applied group. In the CP with Royal Jelly applied groups, Royal Jelly restored the CPinduced structural alterations in the liver tissue by the way of its antioxidant.

DISCUSSION AND CONCLUSION: Royal Jelly may be a potential preventive natural product against the hepatic toxicity associated with CP therapy.
\end{abstract}

Keywords: Cyclophosphamide, Royal Jelly, Liver, Histopathology

\section{GİRIŞ}

Kanser, canlı hücrelerin anormal proliferasyon ve büyümesi ile oluşan bir hastalıktır. Kanser tedavisi için klinik olarak kullanılan çeşitli yöntemler vardır fakat tedavi sürecinde bu yöntemlerin olumsuz etkileri ile karşılaşılması kaçınılmazdır (1). Kanser tedavisinde kullanılan yöntemleri kemoterapi, cerrahi, hormon tedavisi ve radyasyon olarak sınıflandırmak mümkündür. Bunlar arasından kemoterapi, kanser tedavisinde kullanılan en 
yaygın yöntemdir, bu amaçla hastalara kanserli hücrelerin kontrolsüz çoğalmasını önlemek için sistemik olarak antikanser ilaçları verilir (2). Siklofosfamid (CP) en fazla kullanılan antikanser ilaçlarından biridir. $\mathrm{CP}$, hücresel komponentlerden olan DNA, RNA ve proteinlerin sülfidril, karboksil, amino ve fosfat gruplarılya kovalent bağlar kurarak hücrede fonksiyonel bozulmalara yol açar (3). CP, malign lenfomalar, nöroblastom, miyelom, lösemi, adenokarsinom, meme kanseri tedavisinde ve kemik iliği nakli öncesi hazırlık tedavisi olarak yaygin kullanılan antineoplastik bir ilaçtır $(4,5)$. İlacın immünsüpresif etkisi var olduğu için otoimmün hastalıkların tedavisi için immün baskılayıcı bir ajan olarak da kullanılmaktadır (6). Ayrıca bu ilaç amiloidoz, ağır romatoidartrit ve multipl skleroz gibi rahatsızlıkları da tedavi etmektedir $(7,8)$. Yapılan çalışmalarda ilacın tedavi amaçlı kullanıldığı durumlarda yüksek doza bağlı hematolojik, immünolojik, kardiyak, hepatik ve böbrek toksisiteleri ile alakalı zararlı etkilerinin olduğu bildirilmiştir (9-13).

Besinsel antioksidanlar, doğal ürünlerde bulunan faydalı maddelerdir ve özellikle oksidatif stresin azaltılmasında önemli bir role sahiptir (14). Arı sütü, doğal olarak yüksek antioksidan potansiyeli nedeniyle fonksiyonel gida olarak kullanılabilir. Arı sütü işçi arıların (Apismellifera) baş bölgelerindeki hipofaringeal ve mandibular bezlerden salınan kraliçe arı ve genç larvaları beslemek amaçlı üretilen bir besindir $(15,16)$. Bu besin \% $50-\%$

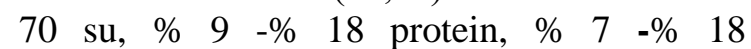
karbonhidrat, \% 3 -\% 8 lipid ve \% 1,5 mineral tuz, enzim, polifenol, hormon ve vitamin içermektedir $(17,18)$. Arı sütünün biyoaktif bileşeni büyük oranda peptidleri, sterolleri ve yağ asitlerini içermektedir. Yapısındaki proteinlerin ve peptidlerin, anyon ve hidroksil radikalleri gibi reaktif oksijen türlerinin azalmasında etkili olduğu bildirilmiştir (19). Ar1 sütünün vazodilatif ve hipotansif aktivitelerine ilaveten büyüme hızındaki artış, dezenfektan etki, antitümör aktivitesi, antienflamatuar, antioksidan, immünmodülatör, antihiperkolestrolemik, hipoglisemik ve yara iyileşme dâhil olmak üzere çeşitli farmakolojik aktiviteler sergilediği bildirilmiştir (20-22). Son y1llarda hasta kişilerin tedavi sürecinde yaşam kalitesinin yüksek tutulmasında daha az yan etkileri olan alternatif doğal ürünlerin kullanımı artış göstermektedir.
Yapılan literatür araştırmalarında da görüldüğü gibi CP'nin tedavi amaçlı kullanımı sonucunda birçok yan etkilerinin olduğu belirtilmiştir. Fakat arı sütünün kemoterapik bir ajan olan $\mathrm{CP}$ uygulanması sonucunda neden olduğu zararlı etkileri azaltıcı ya da bu etkilerden koruyucu bir faktör olduğu ile alakalı bir çalışma mevcut değildir. $\mathrm{Bu}$ nedenle sunulan çalışmada arı sütünün $\mathrm{CP}$ ile oluşabilecek karaciğer hasarına karşı koruyucu bir etki gösterip göstermeyeceği araştırılmıştır.

\section{GEREÇ ve YÖNTEM}

Çalışma için Adıyaman Üniversitesi Hayvan Deneyleri Yerel Etik Kurulu'nun 26.12.2019 tarihli ve 2019-061 kodlu kararı ile onay alınd. 250-300 gr ağırlığında, 32 adet 24 haftalık dişi Wistar albino cinsi siçan her grupta 8 hayvan olacak şekilde 4 gruba ayrıldı. Sıçanlar standart şartlarda (sabit 1s1 ve havalandırmalı odalarda; 12 saat gün 1 şığ 1 ve 12 saat karanlık olmak üzere) ve her gün altları temizlenen kafeslerde ad-libitum olarak beslendi.

Hayvanlar dört eşit gruba ayrıldı:

Grup 1: Kontrol Grubu (0,5 cc serum fizyolojik oral yolla 16 gün süresince verildi.)

Grup 2: Ar1 Sütü Grubu (100 mg/kg arı sütü 16 gün boyunca oral yolla verildi.)

Grup 3: CP grubu $(100 \quad \mathrm{mg} / \mathrm{kg}$ intraperitoneal (Tek doz) CP enjekte edildi. Hayvan 16 gün normal beslendi.)

Grup 4: CP+Arı Sütü grubu $(100 \mathrm{mg} / \mathrm{kg}$ intraperitonealCP enjekte edildi ve ayrica 100 $\mathrm{mg} / \mathrm{kg}$ 'dan her bir sıçana 16 gün boyunca oral yolla arı sütü verildi.)

Toplam 16 gün sonunda ketamine/xylazine anestezisi altında sıçan karaciğer dokuları alındı ve histopatolojik incelemelerde kullanılmak için \%10 luk formaldehit ile fikse edildi. Tespit edilen dokular daha sonra rutin histolojik doku takibi işlemlerinden geçirildi. Son olarak takibi tamamlanan dokulardan kesit almak için parafin bloklar hazırlandi. Parafin bloklardan histopatolojik inceleme yapılabilmesi için $5 \mu \mathrm{m}$ kalınlıkta ince kesitler alındı. Hazırlanan kesitler deparafinize edilerek Hematoksilen Eozin (H\&E) , Masson üçlü boyama ve Toluidin mavi boyama yöntemi ile boyandı. 
Boyanan kesitler Carl Zeiss marka Axiocam ERc5 model dijital kamera ataçmanlı mikroskop ile incelenerek histopatolojik yönden değerlendirildi.

\section{SONUÇLAR}

Kontrol ve arı sütü uygulanan gruplara ait dokuların H\&E ile boyanmış kesitleri incelendiğinde, karaciğer lobülünün ortasında v.centralis, v.centralisten perifere doğru uzanan hepatosit kordonları ve bu kordonların arasinda yer alan sinüzoidlerin normal yapıda olduğu gözlendi (Şekil 1. 1a ve Şekil 2. 2a). Ayrıca poligonal şekilli karaciğer hücrelerinin varlığı izlendi. Hepatosit sitoplazmalarının hücrelerin aktivite durumlarına göre farklı yoğunlukta asidofilik boyanma özelliği gösterdiği saptandı. $\mathrm{Bu}$ hücrelerin çekirdeklerinin merkezi yerleşimli, büyük, yuvarlak ve ökromatik olduğu, bazı hepatositlerin iki çekirdekli olduğu ve normal yapıda oldukları tespit edildi (Şekil 1. 1b ve Şekil 2. 2b). Bağ doku yoğunluğunu değerlendirmek amaciyla Masson üçlü boyama yöntemi ile boyanmış kontrol ve arı sütü uygulanan gruplara ait sıçan karaciğer dokularında, v. centralis çevresinde ve periportal alanda yoğun olmayan bağ dokusu izlendi (Şekil 1. 1c ve Şekil 2. 2c). Toluidin mavisi ile boyanmıs kesitlerde bu gruplara ait damar çevresi bağ dokuda yer alan mast hücrelerinin yoğunluğu normaldi (Şekil $1.1 \mathrm{~d}$ ve Şekil 2. 2d).

CP uygulanmış gruba ait sıçan karaciğer dokularının $\mathrm{H} \& \mathrm{E}$ ile boyanmış kesitleri incelendiğinde, $\mathrm{v}$. centralis çevresinde hepatositlerin oluşturduğu hepatosit kordonlarının düzenlenişinde bozulma olduğu, lobül yapısının ve sinırlarının net olarak ayırt edilemediği karaciğer yapısı gözlendi (Şekil 3. 3a). Ayn 1 gruba ait hepatositlerin hücre bütünlüğündeki bozulmalar nedeniyle hücreler arasındaki bağlantıların bozularak sitoplazmik sınırlarının net olarak ayırt edilemediği, poligonal şekillerinin kaybolduğu, hücreler arasında boyut farklılıklarının ve dejeneratif değişikliklerin olduğu dikkati çekti. Bu hücrelerin bazı alanlarda koyu piknotik çekirdekli bir hal aldığı izlendi (Şekil 3. 3b). Masson üçlü boyama ile yapılan değerlendirmede $\mathrm{CP}$ grubuna ait siçan karaciğer dokularında, v. centralis çevresinde ve periportal alanda kontrol ve arı sütü grubunun aksine yoğun bağ dokusu izlendi. Ayrıca bu sinüzoidal bölgelerde dilatasyon bulgusuna rastlandı (Şekil 3. 3c). Toluidin mavisi ile boyanmış kesitlerde yapılan incelemede damar çevresi bağ dokuda yer alan mast hücrelerinin yoğunluğunun Kontrol ve arı sütü uygulanan gruplara göre belirgin derecede arttığı izlendi (Şekil 3. 3d).

$\mathrm{CP}+\mathrm{Ar} 1$ Sütü uygulanmış gruba ait sıçan karaciğer dokularının H\&E ile boyanmış kesitleri incelendiğinde, Kontrol ve Arı Sütü uygulanan gruplara benzer şekilde hepatositlerin v. centralis etrafında düzenli bir yapılanma gösterdiği izlendi (Şekil 4. 4a). Hepatositlerin normal yapıda olduğu, asidofilik yapılarını koruduğu dikkati çekti. Yer yer dejenerasyona uğramış hepatositlerin varlığının halen devam ettiği ancak yoğunluğunun azaldığı izlendi (Şekil 4. 4b). Masson üçlü boyama ile yapılan değerlendirmede v. centralis çevresinde ve periportal alanda bağ doku yoğunluğunun CP uygulanmış gruba oranla azaldığg, kontrol ve arı sütü uygulanan gruplardakiyle benzer bir görüntü olduğu izlendi (Şekil 4. 4c). Toluidin mavisi ile boyanmış kesit incelemesinde damar çevresi bağ dokuda yer alan mast hücre yoğunluğunun $\mathrm{CP}$ uygulanan gruba göre azaldığı saptandı (Şekil 4. 4d).

Ayrıca hepatik hasarın belirlenmesinde yarı kantitatif histopatolojik skorlama yöntemi kullanıldı (23). 1/25 örnekleme ile alınan kesitler üzerinde rastgele seçilen 10 bölge üzerinde incelemeler yapıldı. İncelemede görülen hasarlanma oranları için skorlamada $0,1,2$ ve 3 şeklinde puanlamalar yapıldı $(0$ : Hasar yok, 1: Az derecede hasar, 2: Orta derecede hasar, 3: Ciddi derecede hasar). Bu sonuçlar tablo da gösterildi.

Tablo. Yarı kantitatif değerlendirme sonucu elde edilen hepatik hasar skorlamasina ait veriler

\begin{tabular}{|l|l|l|l|l|}
\hline $\begin{array}{l}\text { Histopatolojik } \\
\text { Değişiklikler }\end{array}$ & $\begin{array}{l}\text { Kontrol } \\
\text { Grubu }\end{array}$ & $\begin{array}{l}\text { Arı } \\
\text { Süiü } \\
\text { Grubu }\end{array}$ & $\begin{array}{l}\text { CP } \\
\text { Grubu }\end{array}$ & $\begin{array}{l}\text { CP + Ari } \\
\text { Sütü } \\
\text { Grubu }\end{array}$ \\
\hline $\begin{array}{l}\text { Hücresel } \\
\text { Dejenerasyon }\end{array}$ & 0 & 0 & 3 & 1 \\
\hline Fibrozis & 0 & 0 & 2 & 1 \\
\hline $\begin{array}{l}\text { Sinüzoidal } \\
\text { Dilatasyon }\end{array}$ & 0 & 0 & 2 & 1 \\
\hline $\begin{array}{l}\text { Lobüler } \\
\text { Dejenerasyon }\end{array}$ & 0 & 0 & 2 & 1 \\
\hline $\begin{array}{l}\text { Mast Hücresi } \\
\text { Yoğunluğu }\end{array}$ & 0 & 0 & 3 & 1 \\
\hline İnflamasyon & 0 & 0 & 0 & 0 \\
\hline Hemoraji & 0 & 0 & 0 & 0 \\
\hline
\end{tabular}




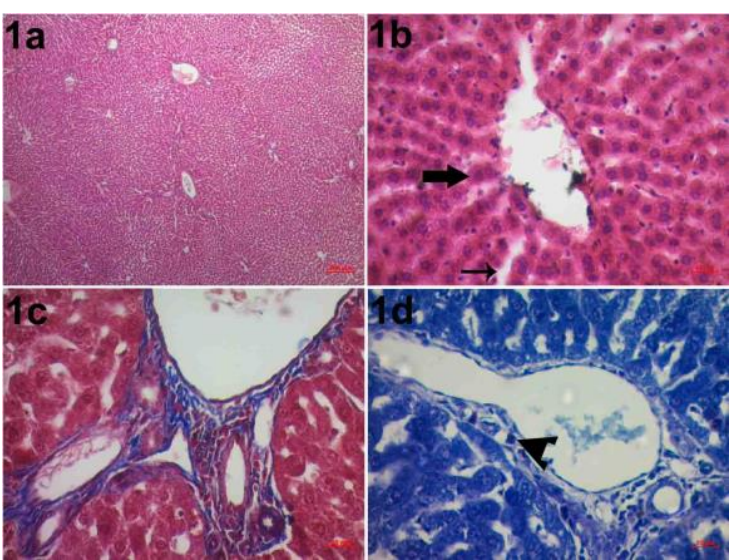

Şekil 1. 1a-1d Kontrol grubuna ait görüntüler (sırasiyla $\mathrm{x} 4$ ve $\mathrm{x} 40^{\prime}$ lık objektif büyütme görüntüleri), kalın ok, sağlıklı hepatosit; ince ok, sinuzoid; ok başı, mast hücresi (Hematoksilen\&Eozin, Masson Üçlü ve Toluidin Mavisi Boyamaları).

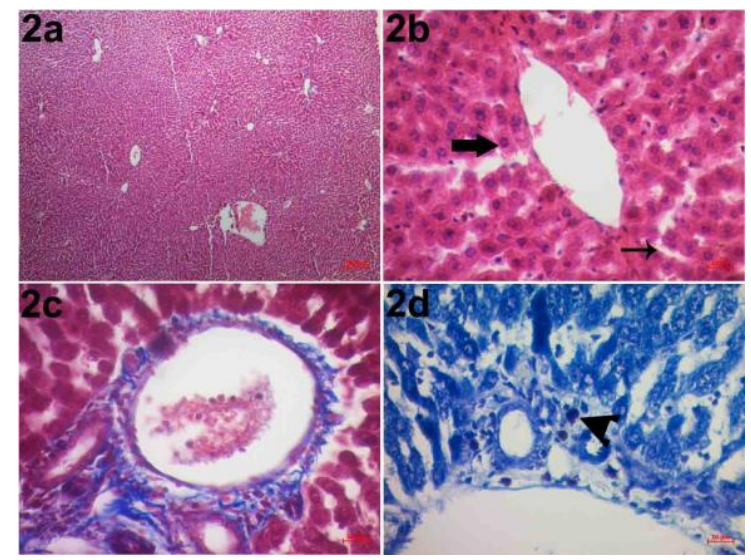

Şekil 2. 2a-2d Ar1 sütü uygulanan gruba ait görüntüler (sırasıyla $\mathrm{x} 4$ ve $\mathrm{x} 40^{\prime}$ 'lık objektif büyütme görüntüleri), kalın ok, sağlıklı hepatosit; ince ok, sinuzoid; ok başı, mast hücresi (Hematoksilen\&Eozin, Masson Üçlü ve Toluidin Mavisi Boyamaları).

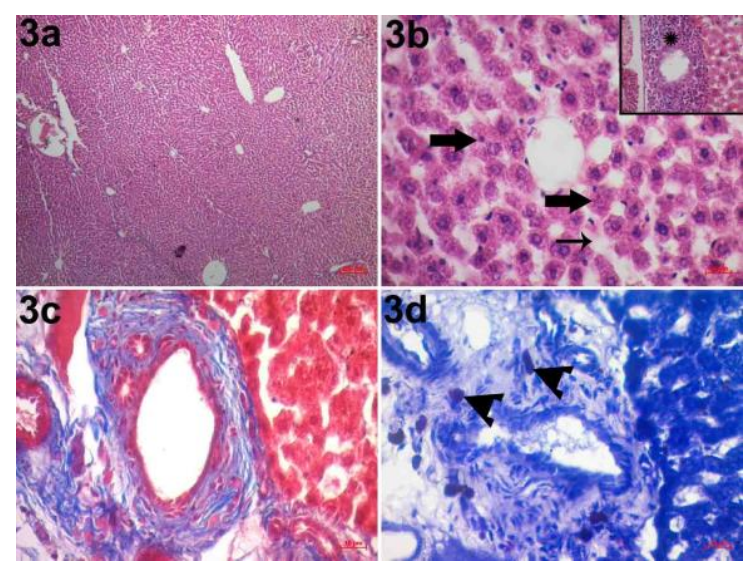

Şekil 3. 3a-3d Siklofosfamiduygulanan gruba ait görüntüler (sırasıyla $x 4$ ve $x 40$ 'lık objektif büyütme görüntüleri), kalın ok, dejenere olmuş hepatosit; ince ok, sinüzoidal dilatasyon; ok başı, mast hücresi (Hematoksilen\&Eozin, Masson Üçlü ve Toluidin Mavisi Boyamaları).

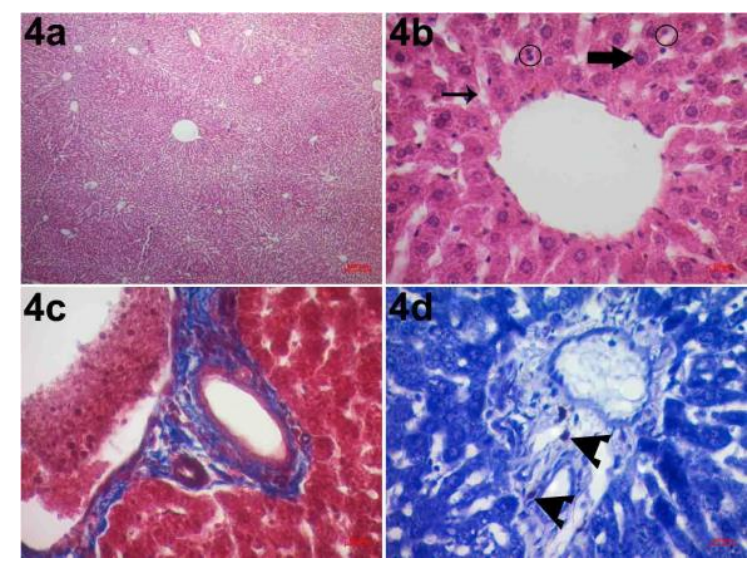

Şekil 4. 4a-4d Siklofosfamidile ar1 sütü uygulanan gruba ait görüntüler (sirasıyla $\mathrm{x} 4 \mathrm{ve}$ x40'l1k objektif büyütme görüntüleri), kalın ok, sağlıklı hepatosit; ince ok, sinüzoid; daire, dejenere olmuş hepatosit; ok başı, mast hücresi (Hematoksilen\&Eozin, Masson Üçlü ve Toluidin Mavisi Boyamaları).

\section{TARTIŞMA}

Kemoterapi, yıllardır kullanılan ve hala kanser için en yaygın tedavi yöntemlerinden biri olmaya devam etmektedir. Kemoterapi ilaçlarının kullanımı esnasında en çok etkilenen normal hücreler arasında saç, kan, sindirim sistemi hücreleri ve genital sistem hücreleridir $(24,25)$. Bu tür ilaçların zararlı yan etkilerinin azaltılmasını sağlamak amacıyla aynı anda kullanılabilecek koruyucu ajanların etkilerini bulmaya yönelik çalıșmalar devam etmektedir (26). İlaç uygulaması sonucunda serbest radikallerin oluşmasıyla birlikte hücrede apoptozla sonuçlanan dejeneratif etkiler ortaya çıkmaktadır. Antioksidan etkili koruyucu ajanlar ise oluşan bu oksidatif stresi ortadan kaldırmayı sağlamaktadır. Bu nedenle destek amaçlı kullanılacak ajan tedavi sürecinde çok önemlidir (27). CP kanser ve otoimmün hastalıkların tedavisinde en çok tercih edilen kemoterapötik bir ajandır. Yapılan çalışmalarda CP kullanımının böbrek, karaciğer, testis, mesane ve beyin gibi birden fazla dokuda toksik etkilerinin olduğuna yönelik bulgulara rastlanmıştır (28-30). Sunulan çalışmada da CP uygulaması sonucu karaciğer dokusunun histopatolojik olarak değerlendirilmesinde 
toksik etkiyi ortaya koyan birçok bulguya rastlanmıştır. Düzensiz hepatosit kordonları, poligonal şekilleri bozulan hepatositler ile koyu piknotik çekirdekli dejenere olan hücrelerin sayısındaki artış CP uygulanan grupta belirgin olarak toksik etkinin varlığını göstermektedir. V. centralis çevresinde ve periportal alanda bă doku yoğunluğunun ve mast hücre sayısının artması ile sinüzoidal bölgelerde dilatasyon bulguları da bu olumsuz etkiyi desteklemektedir. İlacın kullanımı sonucu ortaya çıkan bu toksik etkiler, CP kullanımın sinırlandirılmasına ve hastaların bu tedavi edici etkisinden mahrum kalmasina sebep olan dezavantajlardan bir tanesidir (31).

Anti-kanser aktivite, antioksidan mekanizmalarla güçlü bir şekilde ilişkilidir. Son zamanlarda yapılan çalışmalarda arı sütünün insan sağlığı üzerinde (özellikle üreme sağlığı, nörolojik hastalıklar, yara iyileşmesi, yaşlanma ve kanser) olumlu etkilerinin olduğu bildirilmiştir (32). Birçok bilimsel çalışmada arı sütünün insan sağllğı üzerinde antioksidan, nörotrofik, hipokolesterolemik, doku koruyucu, kan basınc1 düzenleyici, antimikrobiyal, antienflamatuar, immünomodülatör ve antitümör etkileri gözlenmiştir. $\mathrm{Bu}$ etkiler çoğunlukla yapısında bulunan jelleinler, royalisin, majör arı sütü proteinleri (MRJP'ler) ve 10-hidroksi-2-dekenoik asit (10-HDA) gibi biyoaktif maddelerle alakalıdır. İnsan fizyolojisi üzerinde bu maddelerin güçlü farmasötik etkileri vardır (33-36). Arı sütü birincil olarak anti-tümoral etkiler açısından araştırılmıştır. Shirzad ve ark. (37) arı sütünün antitümör etkisine vurgu yapmışlar ve arı sütünün fibrosarkom hücrelerinin kontrolünde ve gerilemesinde önemli rolü olduğunu bildirmişlerdir. $\mathrm{Bu}$ sonuçları arı sütünün immünomodülatör etkisi sonucunda elde ettiklerini bildirmişlerdir. Daha iyi sonuç alınabilmesi için arı sütünün tümör oluşumundan önce kullanılmasını önermişlerdir. Bu çalışmalara ek olarak, İzuta ve ark. (38) özellikle bu etkilerle ilgili doğrudan mekanizmalar belirtmişlerdir. Arı sütünün hücre çoğalmasını ve hücre göçünü inhibe ettiğini ve ayrıca vasküler endotel büyüme faktörünü inhibe ederek tümör vaskülarizasyonunu bozduğunu gözlemlemişlerdir. Sunulan çalışmada da CP ile birlikte arı sütü uygulanan grupta, karaciğer dokusunun histopatolojik değerlendirilmesinde, $\mathrm{CP}$ uygulaması sonucu ortaya çıkan toksisiteye karş1 ar1 sütünün koruyucu etkisinin olduğunu gösteren bulgulara rastlanılmıştır. Hepatosit kordonlarının düzenli şeklini koruduğu, histolojik yapının Kontrol ve arı sütü uygulanan gruplara benzer şekilde olduğu gözlenmiştir. Normal yapıdaki hepatositlerin yoğunluğunun $\mathrm{CP}$ grubundakine göre fazla olduğu dikkat çekmiştir. CP ile birlikte arı sütü uygulanan gruptaki V. centralis çevresinde ve periportal alanda bağ doku yoğunluğu ve mast hücrelerinin sayısındaki azalma bu koruyucu etkiyi desteklemektedir. Rafat ve ark. (39) tarafından yapılan bir çalışmada radyasyon uygulamasına bağlı apoptozun arı sütü ile belirgin şekilde önlenebileceği belirtilmiştir. Deneysel oksidatif hasar sirasında arı sütü verilen farelerin karaciğerleri ve böbrekleri üzerinde güçlü histolojik antioksidan aktivite olduğu bildirilmiştir (40). Silici ve ark. (20) tarafından yapılan benzer bir çalışmada arı sütünün testis, prostat ve epididimal dokulardaki histopatolojik hasarlar üzerinde belirgin derecede iyileştirici etkisi olduğu belirtilmiştir. Ayrıca arı sütünün CP kaynaklı prostat hasarını önemli ölçüde azalttığı, biyokimyasal verileri düzenlediğ gözlemlenmiştir (41). Bahsedilen ilgili bilimsel çalışmalar değerlendirildiğinde, benzer sonuçlar sunulan çalışmanın güvenilirliğini artırmaktadır.

Çalışmamızın ilk limitasyonu mevcut bütçe yetersizliğine bağl1 olarak moleküler ve biyokimyasal parametreler yönünden değerlendirme yapılamamasıdır. $\mathrm{Bu}$ parametrelerin çalışılması çalışmanın güvenilirliğini artırması yönünden önem arz etmektedir. Çalışmamızın bir diğer limitasyonu hayvan grupları açısından örneklem genişliğinin yetersizliğidir. Daha fazla ilave örneklemlerle çalışmanın etkinliğinin artırılabileceği düşüncesindeyiz.

Sonuç olarak sunulan çalışmada, CP'ye maruz kalan deneklerde güçlü bir antioksidan olan arı sütü aracılığıyla karaciğer hasarının azaltıldığı gözlenmiştir. Ancak, oluşan hasarın tamamen ortadan kalktığını analiz etmek için daha ileri çalışmalara ihtiyaç duyulmaktadır. Dokuda teratojen analizlerinin yapılması, CP'ye bağlı hasarın boyutlarının ve arı sütünün tedavi etkinliğinin daha iyi analiz edilmesini sağlayacaktır. Literatürde belirtilen deneysel çalışmaların ve sunulan çalışmanın bulguları dikkate alındığında, arı sütü, terapötik veya bir kombinasyon terapisinin ilgili maddesi olarak 
faydalı olabilecek birçok etki sağlamaktadır. Şu anda doğal ürün olan arı sütünün güvenli ve etkili bir besleyici madde olduğu görülmektedir.

\section{Conflict of interest:None}

\section{References}

1. Zhao G, Rodriguez BL. Molecular targeting of liposomal nanoparticlesto tumor microenvironment. Int Jour of Nanomed. 2013;8:61-71.

2. Jabir NR, Tabrez S, Ashraf GM, Shakil S, Damanhouri GA, Kamal MA. Nanotechnologybased approaches in anticancer research. Int Jour of Nanomed. 2012;7:4391-408.

3. Poblador MS, Rojas C, Raya A, Quiralte J, Casares JA, Lancho-Alonso JL. The effects of cyclophosphamide on the prolactin cells of the normal rat. Histol Histopath. 1989;4:27-30.

4. Morandi P, Ruffini PA, Benvenuto GM, Raimondi R, Fosser V. Cardiac toxicity of highdose chemotherapy. Bone MarrowTransplant.2005;35:323-34.

5. Matz EL, Hsieh MH. Review of Advances in Uroprotective Agents for Cyclophosphamideand Ifosfamide-induced Hemorrhagic Cystitis. Urology. 2017;100:10-6.

6. Perini P, Calabrese M, Rinaldi L, Gallo P. Cyclophosphamide-based combination therapies for autoimmunity. Neurological Science. 2008;29:233-4.

7. Suwa A, Hirakata M, Satoh S, Mimori T, Utsumik K, Inada S. Rheumatoid arthritis associated with methotrexate-induced pneumonitis: Improvement with cyclophosphamide therapy. Clin Exp Rheumatol.1999;17:355-8.

8. Sharda SV, Gulati S, Tripathi G, et al. Do glutathione-S-transferase polymorphisms influence response to intravenous cyclophosphamide therapy in idiopathic nephrotic syndrome? Pediatr Nephrol. 2008;23: 2001-6.

9. Viswanatha-Swamy AH, Patel UM, Koti BC, Gadad PC, Patel NL, Thippeswamy, AH. Cardioprotective effect of Saraca indica against cyclophosphamide induced cardiotoxicity in rats: A biochemical, electrocardiographic and histopathological study. Indian J Pharmacol. 2013;45(1):44-8.

10. Conklin DJ, Haberzettl P, Jagatheesan G, et al. Glutathione S-transferase $\mathrm{P}$ protects against cyclophosphamide-induced cardiotoxicity in mice. Toxicol Appl Pharmacol.2015;285(2):136-48.

11. Amien AI, Fahmy SR, Abd-Elgleel FM, Elaskalany SM. Renoprotective effect of Mangifera indica polysaccharides and silymarin against cyclophosphamide toxicity in rats. $\mathbf{J}$ Basic Appl Zool. 2015;72:154-62.
12. Khorwal G, Chauhan $R$ andNagar M. Effect of cyclophosphamide on liver in albino rats: A comparative dose dependent histomorphological study. International Journal of Biomedical and Advance Research.2017;8(03):102-7.

13. Abdelaziz TE, Borai EBN, Kamal KH, Hanem EG. Contribution of garlic for improving the cytoprotective effect of mesna against cyclophosphamide toxicity in rats. GSC Biological and Pharmaceutical Sciences. 2019;07(03):008-20.

14. Elzoghby RR, Ahlam FH, Abdel-Fatah A, et al. Protective Role of Vitamin C and Green Tea Extract on Malathion-Induced Hepatotoxicity and Nephrotoxicity in Rats. Am J Pharmacol Toxicol. 2014;9:177-88.

15. Pavel CI, Mărghitaş LA, Bobiş $\mathrm{O}$, et al. Biological activities of royal jellyreview. Scientific Papers Animal Science and Biotechnologies. 2011;44(2):108-18.

16. Malkoç M, Altay DU, Alver A, et al. The effects of royal jelly on the oxidant-antioxidant system in rats with $\mathrm{N}$-methyl-N-nitrosourea-induced breast cancer. Turk J Biochem. 2018;43(2):17683.

17. Viuda-Martos M, Ruiz-Navajas Y, FernándezLópez J, Pérez-Álvarez JA. Functional properties of honey, propolis, and royal jelly. J Food Sci. 2008;73(9):117-24.

18. Uçar M. Arı Sütünün Büyüme, Yaşlanma ve Üreme Sağlığına Etkisi. Gümüşhane Üniversitesi Sağlık Bilimleri Dergisi. 2018;7(1):193-202.

19. Nagai $T$, Inoue $R$, Suzuki $N$, Nagashima $T$. Antioxidant properties of enzymatic hydrolysates from royal jelly. J med food. 2006;9(3): 363-67.

20. Silici S, Ekmekcioglu O, Eraslan G, Demirtas A. Antioxidative effect of royal jelly in cisplatininduced testes damage. Urology. 2009;74(3):545-51.

21. Ramadan MF, Al-Ghamdi A. "Bioactive compounds and health-promoting properties of royal jelly: A review". J Funct Foods. 2012;4:39-52.

22. Fratini F, Cilia G, Mancini S, Felicioli A. "Royal Jelly: An ancient remedy with remarkable antibacterial properties". Microbiol Res. 2016;192:130-41.

23. Tovar MC, Sanchez-Valverde MA, Agut A, Laredo FG, Murciano J. Comparative study of air coagulation, fibrin sealant, and suture in experimental liver injury. Eur J Surg. 1998; 164(1): 57-63.

24. Byrne J. Long-term genetic and reproductive effects of ionizing radiation and chemotherapeutic agents on cancer patients and their offspring. Teratology, 1999;59:210-5.

25. Meirow $D$, Lewis $H$, Nugent $D$, Epstein $M$. Subclinical depletion of primordial follicular reserve in mice treated with cyclophosphamide: clinical importance and proposed accurate investigative tool. Hum Reprod. 1999;14:19037.

26. Rajendran L, Knolker HJ, Simons K. Subcellular targeting strategies for drug design 
and delivery. Nat Rev Drug Discov. 2010;9:2942.

27. Prasad KN, Cole WC, Kumar B, Prasad KC. Pros and cons of antioxidant use during radiation therapy. Cancer Treat Rev. 2002;28:79-91.

28. Oboh G, Akomolafe TL, Adetuyi AO. Inhibition of cyclophosphamide-induced oxidative stress in brain by dietary inclusion of red dye extracts from sorghum (Sorghumbicolor) stem. J med food. 2010;13(5):1075-80.

29. Banerjee B, Nandi P, Chakraborty S, Raha S, Sen PC, Jana K. Resveratrol ameliorates benzo(a)pyrene-induced testicular dysfunction and apoptosis: Involvement of p38 MAPK/ATF2/iNOS signaling. J Nutr Biochem. 2016;34:17-29.

30. El-Sheikh AA, Morsy MA, Okasha AM. Inhibition of NF- $\kappa \mathrm{B} / \mathrm{TNF}-\alpha$ pathway may be involved in the protective effect of resveratrol against cyclophosphamide-induced multi-organ toxicity. Immunopharmacology and Immunotoxicology. 2017;39(4):180-7.

31. Selvakumar E, Prahalathan C, Varalakshmi P. Modification of cyclophosphamide-induced clastogenesis and apoptosis in rats by $\alpha$-lipoic acid. Mutat Res-Genet Toxicol Environ. 2006;606:85-91.

32. Pasupuleti VR, Sammugam L, Ramesh N, Gan SH. Honey, propolis, and royal jelly: a comprehensive review of their biological actions and health benefits. Oxid Med Cell Longev 2017;(doi: 10.1155/2017/1259510).

33. Pavel CI, Mărghitaş LA, Bobiş $\mathrm{O}$, et al. Biological activities of royal jelly-review. Scientific Papers Animal Science and Biotechnologies 2011;44:108-18.
34. Cornara L, Biagi M, Xiao J, Burlando B. Therapeutic properties of bioactive compounds from different honeybee products. Front Pharmacol. 2017; (doi: 10.3389/fphar.2017.00412).

35. Viuda-Martos M, Ruiz-Navajas Y, FernándezLópez J, Pérez-Álvarez JA. Functional properties of honey, propolis, and royal jelly. $\mathrm{J}$ Food Sci. 2008;73:117-24.

36. Sı̆̆ AK, Öz-Sığ Ö, Güney M. Royal jelly: a natural therapeutic? Ortadoğu Tip Dergisi. 2019;11(3):333-41.

37. Shirzad M, Kordyazdi R, Shahinfard N, Nikokar M. Does Royal jelly affect tumor cells? J Herbmed Pharmacol. 2013;2:45-8.

38. Izuta H, Chikaraishi Y, Shimazawa M, Mishima S, Hara H. 10-Hydroxy-2-decenoic acid, a majör fatty acid from royal jelly, inhibits VEGFinduced angiogenesis in human umbilical vein endothelial cells. Evid Based Complement Alternat Med. 2009;6(4):489-94.

39. Rafat N, Monfared AS, Shahidi M, Pourfallah TA. The modulating effect of royal jelly consumption against radiation-induced apoptosis in human peripheral blood leukocytes. J Med Phys. 2016;41: 52-7.

40. El-Nekeety AA, El-Kholy W, Abbas NF, Ebaid A, Amra HA, Abdel-Wahhab MA. Efficacy of royal jelly against the oxidative stress of fumonisin in rats. Toxicon. 2007;50:256-69.

41. Abdel-Hafez SMN, Rifaai RA, Abdelzaher WY. Possible protective effect of royal jelly against cyclophosphamide induced prostatic damage in male albino rats; a biochemical, histological and immunohistochemical study. Biomed Pharmacother. 2017;90:15-23. 